\title{
Forests Under Siege: Indigenous Causes of Deforestation in Dir Valley, Pakistan
}

\author{
Furad Ali ${ }^{1}$, Muhammad $\operatorname{Ibrar}^{2} *$, and Syed Asif Ali Shah ${ }^{3}$
}

\begin{abstract}
Deforestation is an alarming worldwide issue whereas the government of Pakistan knows the importance of forests and strives for its preservation. In this respect, an afforestation drive has been kicked off in the country. The aim is to increase the forests resources to thwart the country from the forecast environmental degradation. Moreover, these forests are predicted as the resuscitator of economy of the country in the long run. Besides the afforestation drive, the relentless deforestation is observed in the country. This study is conducted in Asban'r Valley, Dir District of Khyber Pakhtunkhwa province Pakistan to surface the indigenous causes of deforestation. Data was collected through the qualitative research methods including the rapport building, observation, in-depth interviews and key informant interviews. A total of 21 respondents were selected purposively. The descriptive analysis is preferred for the analysis of empirical data. The findings revealed that other causes as highlighted by the various studies and the indigenous causes in the area under study that leads to depletion as reasoned of the political support of timber mafia and locals who cut the trees with collusion of timber mafia and forest officials; and have the competition for the maximization of property among the locals lacking ownership in forest and contumacy of cutting the trees and social disorganization.
\end{abstract}

Keywords: Afforestation; Deforestation; Degradation; Timber Mafia; Collusion; Contumacy.

\section{Introduction}

Forests play a vigorous role in the economy and environment of a country. In contrast, deforestation is a threat to both economy and environment. Deforestation is not a new phenomenon and has its roots in the $19^{\text {th }}$ century. It is defined as the action of clearing a wide area of trees (Meyer, Kooten \& Wang, 2003). Worldwide, deforestation is considered as one of the most intractable cause of environmental degradation. Besides the fact that deforestation leads to the environmental degradation, still the unabated deforestation is observed in the

\footnotetext{
Department of Social Anthropology, University of Peshawar, Khyber Pakhtunkhwa Pakistan.

Department of Social Work, University of Peshawar, Khyber Pakhtunkhwa Pakistan.

3 Department of Environmental Sciences, Informatics \& Statistics, Ca Foscari University of Venice, Italy.
}

*)Corresponding Author.

Email: ibrarswork@uop.edu.pk 
most parts of the world (Hasan, 2007). Allen and Barnes (1985) painted that deforestation in the developing countries is much more than the developed world. The mountains of these developing countries are altering into barren rocks and their land into deserts. Therefore, the causes of deforestation and measures for its control are a matter of considerable concern for researchers, policy makers and state institutions (Meyer et al., 2003) to hinder the way of these causes to preserve forest resources and environment. Numerous studies corroborated the problemoriented consequences of deforestation (Hasan, 2007; Allen \& Barnes, 1985; Ali $\&$ Benjamensin, 2004). Due to the severe nature of the issue, an awareness campaign kicked off for the reservation of forest resources in the world. This campaign for the protective measures of forest resources in the developing countries was initiated in eighth decade of the twentieth century (Allen \& Barnes, 1985).

Pakistan is one among the developing countries which faces the issue of deforestation. Though, Pakistan is a poor country in terms of forest resources because forests covers $4.8 \%$ of the total land area of Pakistan. On the other hand, relentless deforestation is paving the way towards ruining the prevailing forest resources. Among all provinces of Pakistan and Azad Jammu and Kashmir, Khyber Pakhtunkhwa province is considered as the rich in forest resources because it is having forests on about $40 \%$ of its land area. Punjab, Sindh, Baluchistan, Northern Areas, and Kashmir having 14.4\%, 9.4\%, 14\%, 15.7\%, and $6.5 \%$ of forests on its total land area respectively (Hasan, 2007).

The causes of deforestation which are deepened by the researchers that include commercial logging, lack of implementation of forest laws, corruption, ambiguous and imposed property rights, migration, population pressure, ill functioning labor markets, and fuel wood consumption (Meyer et al., 2003). Furthermore, infrastructure and highways are also considered as the observable drivers of deforestation (Allen \& Barnes, 1985). Many scholars do not agree with roads, fuel and population explosion as causes of deforestation. The Theory of Himalayan Environmental Degradation states that population explosion is the main cause of deforestation. However, this theory was criticized and rejected on the basis of empirical data collected in Basho Valley of Baltistan region. It was inferred that population explosion, fuel and grazing are not the causes of deforestation (Ali \& Benjaminsen, 2004). It is observable that on one hand, the cruel attitudes of people towards depletion of forests portrayed in some studies which create a sense of pessimism. On the other hand, some studies terminate the all-embracing cynicism by providing protective measures; and give a hope of the availability of plenty forests in the near and distant future (Hasan, 2007; Allen \& Barnes, 1985). Though, the above causes of deforestation are widely observed by researchers in Pakistan but, the indigenous causes highlighted in this study are of vehemently important to be highlighted and mired. If these causes are not 
hindered, it may convert the forests of Pakistan into barren rocks and in turn may take the region toward global warming, soil erosion, diminution of wildlife, conflicts and economic instability, land sliding and environmental degradation

\section{Classification of Forests in Pakistan}

Forests in Pakistan are mainly divided into two broad categories including Public Forests and Private Forest which are further sub-divided. The provincial government has controlled over the Public Forests. Provincial forest departments have the legal right to intervene in Public Forests. The Public Forests include the Protected Forests, Reserved Forests, and State Forests. The provinces of Punjab, Sindh and Khyber Pakhtunkhwa (previously NWFP) cover Reserved Forests. The local population have no legal right of ownership nor of shares in the Reserved Forests. However, government granted them some rights which encompass the right to graze, to get water from these forests where found the available, to make passages and collect fuel wood. The right of fuelwood is granted to locals to fulfill domestic energy needs from these forests. Approximately, 53\% of the domestic energy needs are fulfilled from these forests annually (Ali \& Benjaminsen, 2004). Protected Forests also come under the umbrella of Public Forests. These forests subsist in all four provinces of Pakistan. The government has privileged the local residents to satisfy all types of non-commercial needs from the Protected Forests. These privileges include cutting trees for noncommercial timber, fuelwood, fodder, passage, water, and grazing. Protected Forests came under the control of government in 1970. Third category of Public Forests are State Forests which occur in Baluchistan and Kashmir. State Forests are controlled by the government and the locals have little privileges of graze, pass, water and fuelwood for domestic needs. Some other categories of Public Forests are resumed Forests and Unclassed forests. The Un-classed Forests are considered as Protected Forests because they still awaiting classification. Nonetheless, the government took over the control of Resumed Forests after land reforms which were carried out in the government of Zulfiqar Ali Bhutto (Hasan, 2007).

The second major type of forests is Private Forests. Private Forests are further divided into Communal Forests and Guzara Forests. Communal Forests are in the Northern Areas of Pakistan. Though, the Communal Forests are regulated by the government now days, but these forests were owned by the community before the amalgamation of Northern Areas in Pakistan. Guzara Forests are owned by the community, but the government has the right to regulate cutting of trees for commercial purposes. The community also has the right to exploit Guzara Forests for commercial gains. Guzara Forests are also called Regulated Forests (Hasan, 2007; Ali \& Benjamensin, 2004). Ideally, the forests of 
the area under study comes under the category of private forests, but not utilized in a sense as private forests are to be utilized in this respect.

\section{Deforestation in Historical Perspective}

The forests in Pakistan came under the control of government in 1878, when forest regulatory procedure was promulgated in the form of Indian Forest Act 1878. This Act provided an aura of legitimacy for government to preserve forests from depletion. The implementation of this Act provoked the people against the government. It created chaos and despair among the people because they argued that the forests are the property of the locals and the government restricts them from further exploitation of forests for their needs (Azhar, 1993). These were only the restrictions of government which irate the locals otherwise, a number of studies revealed that no evidence of commercial exploitation of forests was found in the Sub-continent (Tucker, 1984). On the other hand, a massive deforestation was carried out by the government itself during the British Rule in Sub-continent. A gigantic number of trees were felled for railway tracks and making of ships (Hasan, 2007). Moreover, the Himalayan forests were also exploited in the course of world wars. During World War I and World War II, 400,000 and 440,000 sleepers were supplied from the Himalayan forests to Europe respectively (Hasan, 2007).

Forests mainly cover the hilly areas of Pakistan. It is observed that the hill people are marginalized because they are far away from the center. Thus, the locals fulfill their needs from the forests. When the State extends its control to the forest resources of the hilly areas, and this extension of control resuscitates the struggle of the local people against the government. Forests are controlled by the provincial governments. Forest departments were established for the implementation of forest rules to preserve forests. The forest dwellers have no alternative source of fulfilling their needs hence, they continue the exploitation of forests. This violation of forests rules compelled the government against the forest dwellers and a fragile struggle was kicked off to abolish deforestation (Tucker, 1984).

The government used to harvest trees in all forests of the country to generate revenue. Afore 1973, the forest department sell standing trees to the people. Such the procedure was objected because of the contractors who buy standing trees and use to cut more trees than the permitted limit. More trees were felled with the collusion of officials and contractors. Furthermore, Kalam Integrated Development Project published a report that alleged collusion between the officials of forest department and contractor's results deforestation. This procedure was defamed and ultimately stopped. After defamation of this procedure, Forest Development Corporation (FDC) was established. FDC had been authorized for the harvesting and transportation of timber from forests. The 
FDC tenders the cutting and transportation of timber to market. Though, contractors were also involved in the practice but the difference in the later procedure is this that the contractor has no ownership in trees. It was assumed that if he has no ownership, then there is no need to fell more trees than the tendered limit. After 1977, when the prices of timber increased the FDC again used to tender felled trees. This procedure has a slight difference. FDC harvest trees with the help of labors and then tender them in the forest. Albeit, some authors do not agree with the transparency of the later procedure. They argued that the FDC has created relations with contractors which result in the excessive deforestation. They perceive that the Forest Department and FDC is also a threat to forests (Hasan, 2007).

\section{Afforestation Drives and Causes of its Failure}

Besides, the legal and illegal deforestation; many programs were launched for afforestation for the purpose to overcome the lack of forest resources in the country, but most of the programs were not succeeded in this respect. A report of the provincial government states that the forest dwellers do not allow the Forest Department to plant trees. Moreover, the abundant grazing is a barrier to natural regeneration. The social forestry projects as launched in Kashmir and Northern districts of Khyber Pakhtunkhwa (KP) were rejected by the locals. The locals have a little amount of land for agriculture in the hilly areas. They have no trust over the government and opine that after the maturity of these trees they may lose their land. As the government has taken over the control of forests, and the forest dwellers were not allowed to harvest trees for commercial needs. Moreover, they argued that afforestation reduces grazing (Hasan, 2007).

The provincial government of KP and federal government have initiated Billion Tree Tsunami Project, Green Pakistan, and Tree for Pakistan projects to overcome the lack of forest resources and bar environmental degradation. The government viewed that due to the above projects, the percentage of forests resources in KP has raised the above 4\% in this year (Daily Mashriq, 2019).

\section{Methodology}

This research study based on the qualitative approach including rapport building, observation, in-depth interviews and key informant interviews. Thus, the relevant studies on deforestation highlighted the main causes that regarded as the sensitive issue on account of deforestation which is the source of generating income for the local people.

The respondents hesitate to share such the information with an outsider thus, it was utmost necessary to establish good relationship with respondents so that they can feel free to share information with researcher as Roy (2003) states that after building a good rapport, the respondent will not feel hesitated, sharing 
any required information, and assisting the researcher in different ways. Keeping the rationale of rapport building in mind, the researcher established a good relationship with the respondents. For establishing good relations with the respondents; gaining their trust, and observation, the researcher purchased twenty sleepers of the deforested timber from the locals. Moreover, the researcher gets the help of transporter for carrying the sleepers. The wood cutting machine was used for storing sleepers for a month. With reference of the Timber mafia, a forest official helped the researcher in trafficking the sleepers from the research area to Mardan District of Khyber Pakhtunkhwa. The purpose of purchasing, storing, and trafficking of timber wood was to get plethora information and observe the hidden tactics of timber smuggling. Furthermore, a total of twenty in-depth interviews were carried out with respondents. The respondents include 10 individuals from the local people who use to cut trees on daily basis for economic gains. Timber mafia has great role in deforestation hence, three interviews were carried out with members of timber mafia. The trees were cut down in hilly area. Special vehicles were used to carry timber to plain area. A transporter, who carry the timber wood from hilly area to plain area was interviewed. In the plain area, the timber was stored in a wood cutting machine where trucks and other vehicles were loaded from it to smuggle the timber to the other districts and provinces of Pakistan. The owner of the wood cutting machine was interviewed. Five of the forest officials were interviewed to find out the reasons that why deforestation and timber smuggling is increasing day by day. It is the utmost responsibility of forest department to control deforestation and timber smuggling. Three respondents among the above twenty sample including a local, the member of timber mafia, and the forest official served as key informants. The purpose of key informant interviews was to explore the area and infer the hidden information which was impossible to be deduced in interviews. A political leader as interviewed to highlight the political support of local people who cut trees on daily basis. The respondents were selected through purposive sampling procedure. The empirical data was analyzed through the descriptive analysis.

\section{Findings}

The findings inferred from the field reveals that the indigenous causes for deforestation in Dir District of Pakistan - are vehement political support of locals who cut tress on daily basis and timber mafia, collusion of locals, timber mafia and forest officials, competition among the locals for maximization of property, lack of ownership in forests; social dis-organization; contumacy for cutting trees among the locals; and lack of alternate business or profession. Seven out ten local people, who cut trees on daily basis, were supported by local political leaders. Two of them have close relations with the forest officials. Five of the locals were arrested so many times by the local police on the recommendations of forest 
department. Three of them were fined thirty thousand rupees each. The arrested people were released by the police station in a short span of time due to political pressure. They themselves admit their supports by the political leaders. The timber mafia is powerful as they have close relations with the high ups in forest department and government. One of the members of the timber mafia was identified as the relative of the chief executive of the province. A district forest officer was recently transferred on his approach because he was an obstacle in the way of timber mafia. They pay bribes to the forests official on monthly basis known as Mahwari in their local terminology. The transporter and the owner of the wood cutting machine were having collusion with some forest officials Parting with these causes, it was identified that six of the locals who cut trees on daily basis were economically stable, but they cut trees to maximize their property. Eight among the ten respondents of local community claimed that they did not cut trees for fulfilling their needs, but due to lack of ownership. The forests are not their own property. Though, their ancestors were the owners of these forests, but the government has snatched the ownership right from them; therefore, they cut the trees to maximize their property. They also viewed that if a person cuts one tree the other wish to cut two in contumacy so that they are not left behind in the race of economic gains. There was least social organization in the locals. No one urges another person to stop depletion of forests. They viewed that in the past, if one person cut a tree, the whole village stood against him because it was considered communal property and the village was socially organized in such a way that wood cutter cannot go against the villagers. The social pressure restricts him from cutting trees.

\section{Indigenous Causes of Deforestation}

In the current era, when environmental degradation is predicted all over the world, deforestation became the issue of substantial apprehension for policy- makers and states. Though, it is evident from plethora of studies that deforestation is hazardous for environment and economic stability but the undiminished deforestation is observed in the research area. There are indigenous (local) causes for deforestation in the research area that contribute the thrash of forest resources are as follows:

\section{Support of Local Political Leaders}

Vehement support of the local people who cut trees on daily basis for economic gains, meanwhile the political leaders are observed in the research region in this pattern. It was identified through interview with forest officials that the people who cut trees in the remote areas of the forests are known to them. They even have statistics of the depleted trees on daily basis and receive information from other community members about deforestation daily. They were observed 
helpless to arrest the wood cutters and bar the relentless deforestation. These wood cutters are staunch supporters of the local political leaders. The wood cutters struggle for political leaders during election campaigns and gather people for them during political gatherings. When the forest officials arrest the wood cutters with the help of police. The political leaders including Nazim's and MPA release them by using their political power and approaches to the high ups. The forest officials viewed that the locals were arrested red- handed so many times, but set free without any fine and sanctions. Some of them were rarely fined. For the payment of fine; they cut more trees the locals added. Due to political pressure and support their cases are even not forwarded to the courts, but settled in the police station or forest office. The forest officials further added that once their colleagues were tortured and threatened him to refrain from further visits. The forest official wants to highlight the issue, but intervene and with the support of the officers resolved the issue. Hence, the case remained as the hidden. They further added that in many cases FIR's (First Information Reports) were lodged against the wood cutters, but they were never booked a single time. The nominated accused in the FIR take asylum in the Hujra (Guest House) of the political leader. The political leaders bared the police from the arrest of the alleged criminals. The locals admitted that they were supported by the political leaders. The political support of the local wood cutters resuscitate deforestation. It was identified through interview with a political leader who vehemently supported the wood cutters. With reference to the support of the wood cutters; he added that the government is unable to provide jobs for them. They are marginalized people and far away from the blessings of government. The only way for their income is deforestation. If the government succeed in provision of jobs to one individual from every household: they will themselves refrain from deforestation. Furthermore, he added that he supports them in cutting wood for economic gains because it is the only way to keep them loyal to them in their support. The locals in turn support them in elections. Their vicious circle of supporting each other is hazardous for forests resources in the research area.

\section{Support of Government Office Bearers}

As the support of local wood cutters by the local political leaders and the timber mafia is also vehemently supported by the powerful political leaders of the province. Powerful leaders in a sense who are in the government and exploit the authoritative power to give an advantage the timber mafia. This advantage causes a massive deforestation. It was identified through interview with the forest officials the District Forest Officer who was a very honest and committed officer. He did not allow timber smuggling at any cost. The timber mafia was afraid of him. In the meanwhile, the local timber mafia of the district joined hands with another group from outer district. According to them, one of the members of that 
group was the blood relative of a minister of the province. Another member of the group was having sentimental relations with the leaders of the ruling party of the province. Using their relations and sentimental attachment with the ruling class, the district forest officer was transferred to the far away area of the province. His transferred was a symbol of free hand to the timber mafia. They did not only halt by his transfer, but they succeeded to sporadically appoint the officers of their own choice. The timber smuggling was increased in such a way that it gave rise to the demand of timber. The accomplishment of the demand of timber required the supply of timber on bulky gauge which leads to relentless deforestation.

\section{Collusion of Officials and Timber Mafia}

Collusion between the forest officials and timber mafia founded in the field. The high-grade forest officials were having back-door contacts with the timber mafia that supported the timber mafia to smuggle the timber easily. The back-door involvement of forest officials with the timber mafia was also witnessed in the field. Many of the lower grade officials were unaware of the deals between the timber mafia and forest officials. A case study was carried out which bystander the collusion between timber mafia and forest officials. It was a cold winter evening, one of the forest officials who was a key informant and called by his volunteer informer that a huge amount of timber is loaded in a ten-wheeler vehicle. The key informant called me to accompany him during his visit to the area where the loaded vehicle as observed stayed. Whereas the vehicle was succeeded to cross the forest check post, but stayed for unknown reasons. The key informant assumed that the vehicle might leave at mid night as mid night is the prime time for timber mafia. It was observed that eucalyptus was loaded upon the timber as the trafficking and deforestation of eucalyptus is allowed. We stayed outside the hujra in a tuck shop. Meanwhile, the key informant was called by his colleague to know about his location. He told the story to his colleague. Within the shortest span of time, the key informant was called by his superordinate to leave the area and came back to his post. He insisted that a large amount of timber in going to be smuggled. He is fortunate to trace it. Contrary to his arguments, he was threatened of the consequences with the excuse that the area where he is going to operate that is out of his jurisdiction. He tried his best to convince the officers and his colleague, but all his struggle went in vain. Apathetic and pessimistically he returned back to his post and buzzed angrily that "the whole department is sold". This case study indentured many things. Firstly, it infers that the low-grade forest officials were unaware of the collusion between forest officials and timber mafia. Secondly, the forest officials have links with the timber mafia. The timber was mostly carried on road. Beside the support of the forest officials, it is impossible to smuggle plethora of timber from one district to another and even province. There are a number of check posts on the roads that 
leads from forests to plain areas. Moreover, covert informers serve in the area as well but still the persistent deforestation and smuggling of deforested timber was observed.

\section{Maximization of Property}

It was identified that the local people were in competition for maximization of property which leads to deforestation. Among the sampled population of the local people who cut trees on daily basis, $80 \%$ of them were economically stable. They added that, two to three persons of every household were abroad for earning money in Gulf States. They viewed that they do not deplete forests resources for survival problem or fulfilling basic needs but for the maximization of profit. They further, added that if other locals cut trees, their income increased as compared to them and they will lag in the race of property maximization. Furthermore, they hold the view that in the current era, the value and dignity of a person is measured by the wealth and property one has. If they don't follow others in cutting trees, they would not be able to have cars, cemented houses, hujras, good food, clothes and other movable and immovable properties. To accomplish the aforesaid things and embrace themselves in the race of economy, they cut trees.

\section{Considering Forests as their Ancestral Property}

The sampled population of the local people added that their fathers and grandfathers have the right to cut trees for building houses and selling it in time of need. They have the right to graze cattle, built houses in forest, built pedestrians and commercial logging. From the recent past, the government has snatched all these rights from them. The forests grown up by their fore fathers became the government property. They were deprived from the right of ownership in forests resources and shares after the legal purchase of forests by the government. According to them, deforestation is a kind of exhibition of severe anger and agitation against the government because the government deprived them from their rights. It was the property of their forefathers and their children have the rights to be benefited from these forests. In contrast, the government is snatching the rights of their children and benefiting the children of the elites of the Sama (plain areas). In answer to a question regarding the illegality of cutting trees, sampled population of the locals belligerently replied that what they are doing with forests is not illegal. They added that these forests are the legacies of their forefathers and only they have the right to get benefits of it. Their due right is snatched by the government and now it became their duty to snatch back their rights from the government either by hook or crook. 


\section{Contumacy}

By nature, Pakhtoons are stubborn and contumacious (Macedo, et al., 2012). When one person adopts a way of earning money, the other mostly adopt the same way with more zeal and zest to earn more. The same was the case in the research area. The locals viewed that if one person cuts one tree to generate revenue, his relative or neighbor endeavor to cut more trees. The same mindset was found among all the sampled population of the local people. This contumacy of cutting trees among the locals caused massive deforestation.

\section{Social Disorganization}

Social organization plays a dynamic role in the development of a society (Rafiq, 2003). The local people of the research area were socially disorganized. Seven respondents opined that in the past the village was socially organized. The forests were protected in the way that if one person cut a single tree, the villagers interfere to stop him by requesting and realizing him that these forests are the beauty of their area. Moreover, their cattle graze in these forests and these forests fulfill other necessities like fuel wood, and building woods. In case, the wood cutter did not accept the request of the villagers, they threat him of halting social relationship with him. Due to fear of isolation, the wood cutter unwantedly stop deforestation. In the current era, this village became socially disorganized. People were mostly living in isolation from the main stream village. If one person cuts trees, another person rarely intervenes to stop him. Several conflicts emerged from such interventions. It was identified from a key informant that a month earlier, a person as attempted and axed by a local. He got severe wounds, but survived the attack. His only mistake was intervention to stop a local from cutting trees. Nonetheless like the past, the person who wished to stop deforestation was not backed by the community. Even he was labeled as the agent of government. It was interesting that in the current era, the local people of the community support the wood cutter instead of those who wanted to stop the locals from cutting trees. Due to the altering scenario, no one interferes to stop deforestation. The social disorganization proved hazardous for forest resources in the area intractably caused deforestation.

\section{Conclusion and Recommendations}

The indigenous causes for deforestation were thoroughly observed in the research area. Further, the other causes discussed in literature, the indigenous causes highlighted in this study were of imminent importance. These were intractable causes, if not sorted out and bared, might turn the lush green forests of the country into barren rocks. Moreover, it resuscitates the predicted global warming in the country. Not only were the local people responsible for this environmental and economic loss, but the forest department, politicians, and timber mafia have their 
parts in depleting forests. The forest department officials have collusion with the local people who cut trees on daily basis and timber mafia. They give free hand to some locals and timber mafia to cut and smuggle trees respectively. The political support of the local people and timber mafia not only help them but also assisting the forest department officials. The forests department officials put the responsibility on politicians and exhibit themselves helpless. While on back door, most of the timber mafia and local people who cut trees, hoarding place owner, and transporter who carried timber who were having links with the forest department officials. A precise effort is needed to stop deforestation for the purpose to preserve nature, environment and economy of the country.

As based on the above conclusion, the following recommendations are made to hinder deforestation in Dir Valley.

The government is needed to provide the alternative fuel facility i.e., gas or coal to local inhabitants. Proper demarcation of local dwellers land and government land should be made at the earliest. Deterrence for those officials and local leaders who are involved in deforestation, back supporting timber mafia and collusion. Strict action against timber mafia, wood cutters and suppliers. Last but not the least, it is recommended that the government should provide employment opportunities to the forest dwellers or entrepreneurship schemes so that they can easily establish alternative business for fulfillment of their basic needs.

\section{References}

Allen, C., J., \& Barnes, D. F. (1985). The Causes of Deforestation in Developing Countries. Annals of the Association of American Geographers, 75(2), 163184.

Ali, J., \& Benjaminsen, T. A. (2004). Fuelwood, Timber Deforestation in the Himalayas: The Case of Basho Valley, Baltistan Region, Pakistan. Mountain Research and Development, 24(4), 312-318.

Arif, M. (2019, January 7). Deforestation in Pakistan. Daily Mashriq, p3.

Azhar, R. A. (1993). Commons, Regulations, and Rent-seeking Behavior: The Dilemma of Pakistans Guzara Forest. Economic Development and Cultural Change, 42(19), 115-129.

Hamilton, A. P. F. (1957). Pakistan Re-visited. Empire Forestry Review, 36(1), 3235.

Hasan, L. (2007). An Anatomy of State Failures in Forest Management in Pakistan. The Pakistan Development Review, 46(4), 1189-1203.

Kummer, D., M., \& Turner, B. L. (1994). The Human Causes of Deforestation in South East Asia. BioScience, 44(5), 323-328.

Macedo, Marcia Nunes, Defries, Ruth S., Douglas, C. Morton, \& Shimabukuro, Yosio Edemir, (2012). Decoupling of Deforestation and Soy Production in the Southern Amazon During the Late Two-thousands. Proceedings of the 
National Academy of Sciences of the United States of America, 109, 4, 13411346.

Meyer, A., L., Vankooten, G., C., \& WANG, S. (2003). Institutional, Social and Economic Roots of Deforestation: A Cross-Country Comparison. The International Forestry Review, 5(1), 29-37.

Roy, I. B. (2003). Anthropology: The Study of Man. New Delhi: At Rajendra Ravindra Printers.

Schaeffer, R. et al. (2005). Underlying Causes of Deforestation. Science New Series, 307(5712), 1046-1047.

Tucker, R. P. (1984). The Historical Context of Social Forestry in the Cumaon Himalayas. The Journal of Developing Areas, 18(1), 341-356. 